\title{
PENGEMBANGAN DESA GIRI SASAK SEBAGAI DESA WISATA DI KECAMATAN KURIPAN KABUPATEN LOMBOK BARAT
}

\author{
Imanuella Romaputri Andilolo ${ }^{1}$, I Dewa Gede Bisma², SulaemanSarmo3, \\ Burhanuddin ${ }^{4}$
}

Jurusan Manajemen - Universitas Mataram

irandilolo@gmail.com

\begin{abstract}
ABSTRAK
Dusun Perendekan Selatan merupakan salah satudusun di Desa Giri Sasak Kecamatan Kuripan Kabupaten Lombok Barat Nusa Tenggara Barat. Salah satu potensi wisata di dusun perendekan selatan ini adalah batu kelambu dan bumi di atas awan. Selama ini, masyarakat dusun perendekan tidak memahmi potensi yang dimiliki, oleh karena itu kami tim pengabdian memberikan penyuluhan mengenai bagaimana mengembangkan desa menjadi sebuah desa wisata pada kelompok sadar wisata dusun perendekan selatan. Kegiatan pengabdian ini dilaksanakan dengan cara memberikan penyuluhan mengenai pembuatan paket wisata, industry kreatif dan homestay. Metode yang digunakan adalah dengan mengadakan penyuluhan pengembangan desa wisata meliputi ceramah, tanya jawab, demonstrasi, latihan atau praktek, display. Hasil penyuluhan menunjukkan bahwa masyarakat dusun perendekan selatan mampu membuat paket wisata ke batu kelambu, dan membuat gapura dari bambu serta menyediakan homestay yang bersih dengan dilengkapi kamar mandi dan mampu berkomunikasi yang baik dengan wisatawan.
\end{abstract}

Kata Kunci: Penyuluhan, Kelompok Sadar Wisata, Kerajinan

\begin{abstract}
Perendekan Selatan is one of the hamlets in the village of Giri Sasak, Kuripan Sub-district, West Lombok Regency, West Nusa Tenggara. One of the tourism potentials in Perendekan Selatan hamlet is Batu Kelambu and Bumi Diatas Awan. So far, the people of Perendekan hamlet do not know the potential they have, therefore our community service team provides counseling on how to develop a village into a tourist village in the tourism-awareness community of Perendekan Selatan hamlet. This service activity was carried out by providing counseling on the making of tour packages, creative industries and homestays. The method used is to hold a tourism village development counseling including lectures, questions and answers, demonstrations, exercises or practices, displays. The results of the counseling show that the people of Perendekan Selatan hamlet
\end{abstract}


are able to make tour packages to Batu Kelambu, and make bamboo gates and provide clean homestays with bathrooms and are able to communicate well with tourists.

Keywords: Counseling, Tourism-Awareness Community, Crafts

\section{PENDAHULUAN}

Dusun perendekan selatan berada di wilayah desa giri sasak kecamatan kuripan kabupaten lombok barat. Salah satu daya tarik yang berpotensi untuk dijadikan sebagai wisata di dusun perendekan selatan adalah memiliki batu kelambu. Selain itu juga memiliki keunikan dan daya tarik tersendiri yakni hutan bambu beserta kera-kera yang menghuninya serta memiliki daerah yang masih kental alam pedesaannya dan masih kental dengan tradisionalitasnya, sehingga sangat cocok untuk dikembangkan sebagai Desa Wisata.

Desa wisata menawarkan pengalaman baru, yaitu menyatu dengan alam pedesaan, menghirup udara segar, jauh dari polusi dan kebisingan, merasakan dan terlibat dalam aktivitas masyarakat setempat, artinya wisatawan tidak hanya melihat begitu saja keindahan alam, tetapi dapat hidup di dalamnya. Wisatawan dapat merasakan dan menikmati secara utuh alam dan sosial budaya di desa tersebut. Cara menggali, memanfaatkan, dan membangun sumber daya lokal yang selama ini kurang mendapat perhatian, mengurangi kebocoran, serta untuk meningkatkan pendapatan berganda masyarakat desa setempat, serta untuk menyeleksi segmen pasar wisatawan yang berorientasi pada budaya dan peduli lingkungan, serta menawarkan akomodasi berupa homestay yang hygiene dengan sanitasinya. Mengenai makan dan minum dilayani oleh penduduk sendiri, baik secara unit keluarga maupun secara kolektif dengan aksentasi makanan setempat. Di samping itu, atraksi yang ditawarkan berupa perjalanan melihat suasana keseharian, pengolahan sawah/ladang/pekerjaan kesenian rakyat di desa serta pembuatan cinderamata berupa kerajinan bambu. Oleh karena itu diharapakan masyarakat lebih mendukung pengembangan kepariwisataan, khususnya Dusun perendekan selatan desa giri sasak dengan melihat potensi yang ada untuk menjadikan salah satu dusun yang menunjang 


\section{Jurnal ABDIMAS INDEPENDEN}

desa giri sasak sebagai Desa Wisata. Berdasarkan permasalahan di atas, maka tujuan kegiatan pengabdian ini adalah untuk : 1) meningkatkan pemahaman mengenai pengembangan desa wisata dengan membuat paket wisata2)meningkatkan pengetahuan mengenai teknik industry kreatif. 3) meningkatkan pengetahuan mengenai pengelolaan homestay.

\section{METODE KEGIATAN}

Pengabdian yang dilaksanakan di desa giri sasak dusun perendekan selatan, dengan tema pengembangan desa menjadi desa wisata diadakan selama 4 bulan antara bulan Agustus hingga November. Metode yang digunakan untuk memecahkan masalah dalam memberdayakan kelompok sadar wisata dusun perendekan selatan adalah:

a. Ceramahdan Tanya jawab, dengan kelompok sadar wisata dusun perendekan selatan dengan jumlah peserta 20 orang untuk menjelaskan pengembangan desa wisata lokasi di kaki gunung sasak dusun perendekan dengan mengggunakan LCD dan pengeras suara.

b. Demonstrasiuntukmenjelaskansuatupengembangan desa wisata.Dengancara bekerja sama dengan kelompok sadar wisata dengan membuat desain wisata contoh membuat gapura dari bambu, penunjuk jalan di pintu masuk dan membuat tempat parkir.

c. Peninjauan desa dalam menciptakan atau pengembangan desa wisata dengan melihat potensi desa untuk menjadikan desa ekowisata misalnya pembuatan kerajinan bambu dan produk olahan pangan, dengan cara membuat catatan untuk ditindaklanjuti oleh desa giri sasak agar disediakan anggaran desa dalam pengembangan desa ekowisata ini.

d. Peninjauan rumah warga untuk dijadikan sebagai homestay, dengan memberikan catatan mengenai layak ataukah tidak serta hal-hal apa yang diperlukan apabila mau menjadikan rumah warga menjadi homestay. 


\section{HASIL DAN PEMBAHASAN}

Adapun beberapa hasil dari pelaksanaan kegiatan pengabdian ini adalah:

1. Pemahaman pengembangan desa wisata dan pembuatan paket wisata

Pemahaman pengembangan desa wisata ditujukan kepada kelompok sadar wisata dusun perendekan selatan dengan cara memberikan penyuluhan mengenai suatu bentuk kegiatan wisata dengan cara menyuguhkan wisata yang alami dan dikelola dengan pendekatan konservasi dan mengedepankan kesejahteraan masyarakat setempat. Masyarakat menjadi basis utama dalam pengembangan konsep wisata ini, sehingga didapatkan poin penting yaitu tentang konservasi dan kesejahteraan.

Ekowisata bila ditinjau dari perannya dalam hal konservasi, berarti lebih menjurus pada kelestarian lingkungan yang berkelanjutan. Sedangkan jika berbicara tentang kesejahteraan, maka berkaitan erat dengan pengelolaan dan pemanfaatan yang berujung pada peningkatan pendapatan. Peningkatan pendapatan masyarakat dirasa sangat penting dan menjadi tujuan utama dalam menjalankan konsep pengembangan desa wisata berbasis ekowisata. Oleh karena itu penyuluhan ini tidak hanya memberikan pemahaman mengenai pengembangan desa wisata tetapi juga menjelaskan cara membuat paket wisata, misalnya dalam hal ini dusun perendekan memilik potensi wisata batu kelambu, maka bagaimana cara membuat paket wisata batu kelambu ini, mulai dari wisatawan datang sampai dapat mencapai batu kelambu untuk menikmati sunrise, dimana para wisatawan akan menginap di atas bukit sambil menikmati pemandangan malam sambil menunggu pagi, sehingga memerlukan guide/pemandu. Sehingga fasilitas-fasilitas apa saja yang akan disediakan oleh masyarakat terkait pariwisata ini yaitu mulai dari tempat parkir, kamar mandi, bahkan sampai homestay dan adanya suatu jaminan keamanan. 


\section{Jurnal ABDIMAS INDEPENDEN}

Vol. 2, No. 1, Mei 2021

2. Pengetahuan teknik industry kreatif

Ekonomi Kreatif akan menjadi trend ekonomi dunia dalam beberapa tahun mendatang (Arifianti dan Alexandri, 2017). Oleh karena itu kreativitas dalam berkehidupan ekonomi yang memaksimalkan nilai tambah dari suatu produk barang dan jasa dalam rangka keberlanjutan kehidupan dan peradaban manusia mutlak diimplementasikan oleh semua masyarakat. Kegiatan pengabdian ini dilaksanakan untuk memberikan pemahaman kepada masyarakat dusun perendekan dalam membuat suatu kreativitas yang dapat menghasilkan nilai tambah atau pendapatan tambahan dari sector pariwisata. Kreativitasnya meliputi bagaimana masyarakat mampu untuk membuat kerajinan (craft) dimana kegiatan yang berkaitan dengan kreasi, produksi dan distribusi produk yang dibuat atau dihasilkan oleh tenaga pengrajin yang berawal dari desain awal sampai proses penyelesaian produknya, antara lain meliputi barang kerajinan dari bambu. Kerajinan bambu ini awalnya hanya membuat perlengkapan rumah tangga seperti tempat nasi. Tim pengabdian ini, memberikan pelatihan pengolahan bambu terkait dengan destinasi wisata misalnya membuat pintu masuk untuk wisata batu kelambu, beberapa petuntuk arah dan pagar untuk tempat parkir yang terbuat dari bambu dengan desain yang baik.

3. Pengetahuan pengelolaan homestay

Homestay juga sebagai suatu usaha akomodasi dibidang pariwisata umumnya dibangun di derah pedesaaan (rural destination), diharapkan mampu memberikan kesejahteraan bagi masyarakat desa, selain wisatawan diberi tempat menginap, dapat merasakan dan mempelajari secara langsung lingkungan alam dan budaya setempat (unik dan menarik), tentunya dengan "membayar" berbagai hal seperti, fasilitas ruangan menginap yang bersih, peralatan makan minum yang bersih (Lasibey, 2020). Oleh karena itu, kami tim pengabdian memberikan edukasi kepada masyarakat dusun perendekan dalam menjaga lingkungan dusun khususnya rumah yang akan dijadikan homestay dengan cara menjaga kebersihan ruangan untuk menginap, 
peralatan makan minum termasuk kamar mandi yang akan menjadi kebutuhan bagi para wisatawan. Selain itu tim juga memberikan penyuluhan bagaimana berkomunikasi yang baik dengan para wisatawan, hal ini dilakukan karena menunjang dari keberadaan homestay, dimana ada beberapa ruangan yang digunakan secara bersama, sehingga dengan komunikasi yang baik akan membuat para wisatawan menjadi betah untuk tinggal di homestay.

Berdasarkan metode penyuluhan yang dilaksanakan oleh tim pengabdian di dusun perendekan selatan diperoleh hasil bahwa masayarakat mampu memahami mengenai cara mengubah desa giri sasak menjadi desa wisata, hal ini terlihat dari upaya masyarakat yang sudah melakukan aktivitas yang mendukung sector wisata diantaranya sudah ada gapura pintu masuk ke batu kelambu, anakanak muda sudah mulai belajar bahasa inggris, masyarakat sadar akan pentingnya hidup bersih dan menyediakan tempat parkir bagi wisatawan, homestay dan tersedia kamar mandi yang bersih serta kemampuan di dalam berkomunikasi dengan wisatawan.

\section{Gambar: Wisata Sunrise dan Negeri di Atas Awan Dusun Perendekan Selatan}
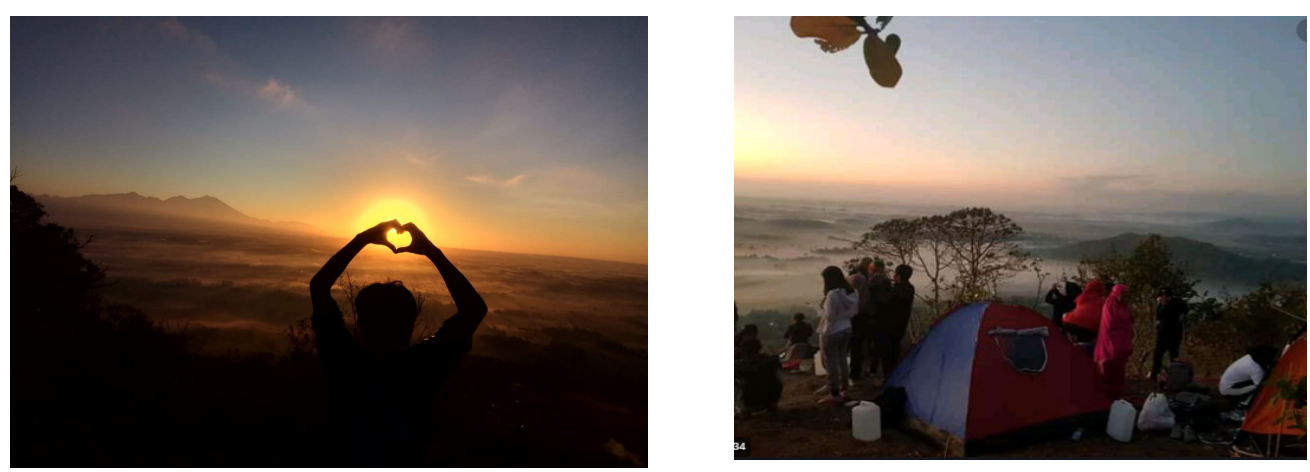

\section{Gambar:Pintu Masuk terbuat Dari Bambu}

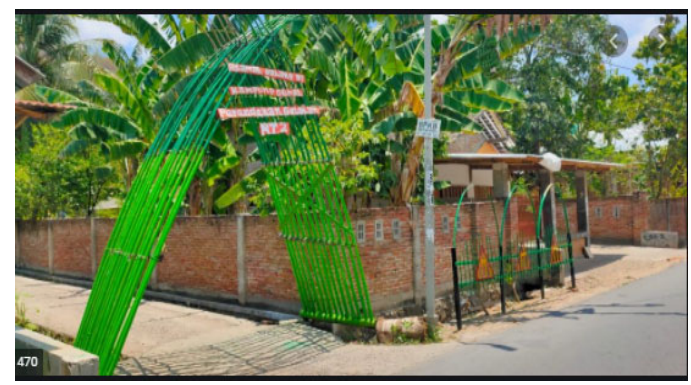




\section{Jurnal ABDIMAS INDEPENDEN}

\section{SIMPULAN DAN SARAN}

\section{Simpulan}

Berdasarkan pembahasan dari kegiatan pengabdian ini maka, kesimpulannya adalah: a) Masyarakat dusun perendekan selatan sudah memahami mengenai konsep pengembangan desa wisata dan sudah dapat membuat paket wisata ke batu kelambu untuk melihat sunrise; b) Masyarakat dusun perendekan selatan sudah memahami mengenai teknik industry creative dalam bentuk pengolahan bambu menjadi barang seni, misalnya gapura pintu masuk, perlengkapan dapur; c) Masyarakat dusun perendekan selatan sudah memahami konsep homestay, sehingga sudah mulai membersihkan lingkungan, belajar bahasa inggris dan menyediakan kamar mandi di rumah yang dijadikan homestay.

\section{Saran}

Tim pengabdian memberikan saran kepada mitra untuk terus menerapkan apa yang sudah dilatih misalnya menjaga kebersihan lingkungan, sering membuat paket wisata yang berbeda, menghasilkan karya dari bahan baku lokal.

\section{UCAPAN TERIMA KASIH}

Pelaksanaan kegiatan Pengabdian Kepada Masyarakat ini telah melibatkan berbagai pihak, oleh karena itu pada kesempatan ini kami mengucapkan terima kasih dan penghargaan kepada :

1 LPPM UNRAM selaku koordinator pelaksanaan pengabdian kepada masyarakat.

2 Fakultas Ekonomi dan Bisnis Universitas Mataram dan BP2EB Fakultas Ekonomi dan Bisnis Universitas Mataram.

3 Ketua kelompok sadar wisata dusun perendekan selatan desa giri sasak kecamatan kuripan kabupaten Lombok barat. 


\section{DAFTAR PUSTAKA}

Anonim. 2018. Kabupaten Lombok Barat Dalam Angka. Pusat Statistik Kabupaten Lombok Barat.

Arifianti, Ria dan Alexandri, Mohammad Benny.2017. Activation Of Creative SubEconomic Sector in Bandung City. Jurnal AdBispreneur Vol. 2, No. 3, Desember 2017 Hal. 201-209

Lasibey, Ariance Ana. 2020. Pengelolaan Homestay Lopo Mutis Di Desa Wisata Fatumnas.JUPAR-Jurnal Pariwisata.Vol 3 No 1 Mei 2020

Putra, Agus Muriawan. 2006. Konsep Desa Wisata (Jurnal Manajemen Pariwisata, ISSN No. 1412 - 1263)". Denpasar: STIE.

Robbins, Stephen, 2006, "Perilaku Organisasi”, Prentice Hall, edisikesepuluh

Sulastriningrum,Sri; Noviyanti, fifi; Fitriana,Rina.2018. Pelatihan Peningkatan Kualitas SDM Bidang Pariwisata Di Desa Wisata. Jurnal Solma Vol 7 (2) 176181 